\title{
OPTIMASI PRODUKSI USAHATANI SAYURAN ORGANIK (Studi Kasus Yayasan Bina Sarana Bakti, Cisarua, Bogor)
}

\author{
Muh Saiful Djafri ${ }^{1)}$, Harianto ${ }^{2)}$, dan Yusman Syaukat ${ }^{3)}$ \\ 1)Program Studi Ilmu Ekonomi Pertanian, Sekolah Pascasarjana, Institut Pertanian Bogor \\ ${ }^{2}$ Departemen Agribisnis, Fakultas Ekonomi dan Manajemen, Institut Pertanian Bogor \\ ${ }^{3)}$ Departemen Ekonomi Sumberdaya dan Lahan, Fakultas Ekonomi dan Manajemen, \\ Institut Pertanian Bogor \\ ${ }^{1)}$ saiful0305@gmail.com
}

\begin{abstract}
The organic farming potential is relatively large because of the high economic benefits for farmers and it is beneficial to operate. The research carried out as an idea or information to change the paradigm of organic farmers through an approach towards research on the income aspects of organic farming by production analysis. Yayasan Bina Sarana Bakti (YBSB) is the selected organic companies in the study. The objectives of this study are (1) analyze the level of organic vegetable production optimization Yayasan Bina Sarana Bakti and the level of use of resources (2) identify changes in profit in optimal conditions Yayasan Bina Sarana Bakti (3) analyze the effect of changes in prices of production inputs and outputs to the optimal production conditions. Production optimalization analysis of organic farming in view of income changes is a right thing to do. Linear programming analysis was used in this research. The results showed that Yayasan Bina Sarana Bakti as an agribusiness company in organic vegetable production has yet to produce optimally. Optimal conditions of the company turned out to show the change in resources optimal use of resources which have not occurred on the land surplus amounted to 10.06 percent and profits at optimal conditions which is higher than the actual which profits can be increased 57,86 percent.
\end{abstract}

Keyword(s): organic farming, production optimization, linear programming, profit

\begin{abstract}
ABSTRAK
Potensi pertanian organik tergolong besar karena memberikan keuntungan tinggi secara ekonomi bagi petani dan layak untuk diusahakan. Penelitian dilakukan sebagai gambaran atau informasi untuk mengubah paradigma petani menuju organik melalui pendekatan penelitian terhadap aspek pendapatan pertanian organik melalui analisis produksinya. Adapun perusahaan organik yang dipilih dalam penelitian yaitu Yayasan Bina Sarana Bakti (YBSB). Tujuan dari penelitian ini adalah (1) menganalisis tingkat optimasi produksi sayuran organik Yayasan Bina Sarana Bakti dan tingkat penggunaan sumberdayanya (2) mengidentifikasi perubahan keuntungan yang terjadi pada kondisi optimal terhadap kondisi actual Yayasan Bina Sarana Bakti (3) menganalisis pengaruh perubahan harga input dan output produksi terhadap kondisi produksi optimal. Analisis optimasi produksi dari pertanian organik dalam melihat suatu perubahan dalam pendapatan adalah salah satu hal tepat yang dapat dilakukan. Analisis penelitian menggunakan program linear. Hasil diperoleh bahwa Yayasan Bina Sarana Bakti sebagai perusahaan agribisnis di bidang produksi sayur organik ternyata belum berproduksi secara optimal. Kondisi optimal perusahan ternyata menunjukkan terjadinya perubahan pada sumberdaya, sumberdaya yang digunakan belum optimal dimana terjadi surplus pada lahan sebesar 10,06 persen dan keuntungan yang diperoleh pada kondisi optimal lebih tinggi daripada kodisi aktual, keuntungan masih bisa dicapai sebesar 57,86 persen.
\end{abstract}

Kata Kunci: pertanian organik, optimasi produksi, program linear, keuntungan 


\section{PENDAHULUAN}

Kegiatan usahatani komoditas sayuran khususnya sayuran organik saat ini mulai banyak dikembangkan, komoditas ini juga sangat potensial dan prospektif untuk dijalankan karena metode pembudidayaannya sangat mudah dan sederhana. Strategi pengembangan agribisnis sayuran diarahkan pada upaya pengembangan produksi sesuai dengan kebutuhan, penciptaan pola tanam/pola produksi yang merata sepanjang tahun (Taufik, 2012).

Peluang bisnis produk pertanian organik ini sudah mulai banyak dimanfaatkan terbukti adanya peningkatan jumlah lahan pertanian organik Indonesia berdasarkan data Statistik Pertanian Organik Indonesia (Ariesusanty et al., 2010). Melihat perkembangan dunia pangan khususnya produk pertanian dewasa ini, sudah menjadi keharusan apabila pertanian dilaksanakan secara organik. Potensi mengembangkan pertanian organik di Indonesia terbilang sangat terbuka lebar dan keuntungannya sangat besar. Hal ini sesuai dengan beberapa penelitian yang dilakukan (Rubinos et al., 2007) menyatakan bahwa pertanian organik merupakan usahatani yang mampu memberikan keuntungan secara ekonomi bagi petani dan layak untuk diusahakan, karena mempunyai harga produksi premium dan memiliki viabilitas tinggi secara ekonomi dibanding dengan usahatani konvensional. Menurut (Sugiono, 2010), bahwa keuntungan dari pertanian organik lebih baik daripada pertanian konvensional terutama jika ada integrasi antara produksi dan pemasarannya.
Pembangunan pertanian organik berwawasan lingkungan di Indonesia merupakan suatu konsep pembangunan pertanian berkelanjutan dengan tujuan untuk meningkatkan keuntungan dan kesejahteraan. Hal tersebut bisa dicapai melalui peningkatan produksi pertanian organik baik dari segi kuantitas maupun kualitas, (Sulaeman, 2009). Saat ini masih banyak petani (produsen) yang belum beralih dari pertanian konvensional ke pertanian organik salah satu penyebabnya karena kemungkinan risiko yang dihadapi pertanian organik lebih tinggi sehingga memicu keuntungan yang diperoleh rendah termasuk perusahaan pertanian khususnya, sehingga menjadi dilema bagi produsen. Menurut (Widiarta, 2011), semakin terbukanya pasar organik ternyata masih belum membuat Indonesia cukup mampu menjadi produsen utama produk organik di dunia.

Berdasarkan laporan survey bahwa jumlah produsen dan luas lahan organik di Indonesia semakin rendah disamping itu pertanian konvensional relatif berkembang. Realita tersebut cukup ironis dan bertolakbelakang dengan teori pertanian organik yang dikemukakan para ahli. Beberapa referensi teori menyatakan bahwa pertanian organik berpengaruh positif terhadap keberlanjutan ekologi dan ekonomi petani atau produsen organik, namun kenyataannya masih banyak produsen atau perusahaan pertanian belum menjalankan praktik pertanian organik dan cenderung konvensional. Perbedaan nyata antara teori dan realita praktik pertanian organik di kalangan produsen (petani) inilah 
kemudian menimbulkan pertanyaan besar yang penting diteliti lebih lanjut. Upaya untuk mengubah paradigma produsen (petani) menuju organik didukung dengan aspek ekonomi berupa pendapatan yang menjanjikan dari pertanian organik. Analisis optimasi dari pertanian organik untuk melihat suatu perubahan dalam pencapaian pendapatan kemudian menjadi salah satu hal yang tepat yang dapat dilakukan untuk menjawab fenomena di atas.

Jawa Barat merupakan salah satu sentra sayuran di Indonesia karena didukung dari iklim, cuaca dan kondisi tanahnya sehingga beberapa pengusaha yang mengusahakan sayuran terutama sayuran organik dan salah satunya adalah daerah Bogor. Yayasan Bina Sarana Bakti merupakan salah satu produsen sayuran organik dan melakukan pembudidayaan dan pemasaran komoditas organik dengan penjaminan organik berbasis komunitas (Participatory Guarentee System). Perusahaan Yayasan Bina Sarana Bakti berupaya melakukan strategi pengelolaan usahatani dan produksi dengan baik untuk memenuhi permintaan pasar. Sebagai perusahaan pertanian, sumber utama dari kas perusahaan berasal dari bagian produksi. Perusahaan seringkali dihadapkan pada keterbatasan sumberdaya (input), namun walaupun demikian keuntungan yang maksimum akan selalu menjadi prioritas yang ingin dicapai perusahaan untuk tujuan jangka pendeknya. Untuk itulah optimasi produksi dari item-item produk maupun kombinasi penggunaan input perlu mendapat perhatian khusus (Diatin, 2006).
Manajemen produksi pada suatu perusahaan akan selalu berusaha untuk mengatur dan merencanakan penggunaan faktor-faktor produksinya agar mampu berproduksi dengan biaya minimum dengan mencapai keuntungan pada tingkat tertentu. Oleh karenanya perlu dirumuskan perencanaan usahatani dengan mengkombinasikan berbagai input dalam berbagai karakter keterbatasan untuk memaksimumkan keuntungan. Tujuan perusahaan dalam memaksimalkan keuntungan ataupun meminimumkan biaya produksi dapat tercapai melalui perencanaan optimasi produksi. Optimasi merupakan pencapaian suatu keadaan yang terbaik, yaitu pencapaian suatu solusi suatu permasalahn (Soekartawi, 1992).

Penelitian dilakukan atas dasar sebagai gambaran untuk mengubah paradigma produsen atau petani menuju organik yang didukung dengan aspek ekonomi berupa pendapatan yang menjanjikan dari pertanian organik melalui pendekatan analisis optimasinya, khususnya pada usahatani komoditas sayuran, kedua adalah sebagai objek yang dipilih, maka penelitian dilakukan pula atas dasar kebutuhan perusahaan terhadap suatu analisis mengenai kebijakan produksinya. Analisis produksi ini diwujudkan dalam bentuk optimalisasi produksi yang bertujuan untuk melihat tingkat produksi optimal yang seharusnya dicapai oleh Yayasan Bina Sarana Bakti yang akan mempengaruhi keuntungan perusahaan. Secara rinci penelitian ini bertujuan untuk (1) menganalisis tingkat optimasi produksi sayuran organik Yayasan Bina Sarana Bakti dan tingkat 
penggunaan sumberdayanya (2) mengidentifikasi perubahan keuntungan yang terjadi pada kondisi optimal terhadap kondisi aktual Yayasan Bina Sarana Bakti (3) menganalisis pengaruh perubahan harga input dan output produksi terhadap kondisi produksi optimal Yayasan Bina Sarana Bakti.
Adapun kondisi produksi aktual dalam satu musim pertama tersaji pada Tabel 1.

\section{METODE PENELITIAN}

Penelitian ini dilakukan pada perusahaan organik yaitu perusahaan Yayasan Bina Sarana Bakti (YBSB) dimana perusahaan ini terletak di Jalan

Tabel 1. Produksi dan Luas Lahan Aktual Musim Tanam Pertama 35 Crop Sayur Organik

\begin{tabular}{|c|c|c|c|}
\hline Komoditi & $\begin{array}{c}\text { Kebutuhan Luas } \\
\text { Lahan }\left(\mathbf{m}^{2}\right)\end{array}$ & $\begin{array}{l}\text { Produktifitas } \\
\text { lahan }\left(\mathrm{kg} / \mathbf{~ m}^{2}\right)\end{array}$ & $\begin{array}{c}\text { Produksi Aktual } \\
\text { (kg) }\end{array}$ \\
\hline Bayam Hijau & 330 & 0.84 & 278.7 \\
\hline Bawang Daun & 30 & 1.66 & 49.9 \\
\hline Bayam Merah & 220 & 0.24 & 53 \\
\hline Bit & 120 & 1.89 & 226.4 \\
\hline Brocoli & 350 & 0.22 & 75.5 \\
\hline Buncis & 190 & 0.59 & 112.5 \\
\hline Cabe Rawit & 50 & 0.61 & 30.3 \\
\hline Caysim & 170 & 2.54 & 431.2 \\
\hline Endive & 30 & 1.22 & 36.6 \\
\hline Jagung baby & 250 & 0.57 & 141.9 \\
\hline Jagung Manis & 280 & 1.00 & 281 \\
\hline Kacang Merah & 150 & 0.38 & 57 \\
\hline Kacang Tanah & 280 & 0.12 & 33.2 \\
\hline Kailan & 150 & 1.46 & 219.1 \\
\hline Kangkung & 270 & 1.05 & 284 \\
\hline Kapri muda & 30 & 0.58 & 17.4 \\
\hline Kapri polong & 30 & 0.31 & 9.3 \\
\hline Kol bulat putih & 190 & 1.43 & 272.3 \\
\hline Kol bunga & 70 & 0.60 & 42.2 \\
\hline Lobak & 40 & 5.41 & 216.4 \\
\hline Pakcoi hijau & 260 & 1.91 & 495.3 \\
\hline Pakcoi putih & 130 & 2.28 & 296 \\
\hline Petsai nagaoka & 300 & 0.87 & 262.2 \\
\hline Selada cos & 140 & 1.71 & 238.7 \\
\hline Selada head & 80 & 0.43 & 34 \\
\hline Selada keriting & 120 & 1.42 & 170.1 \\
\hline Selada merah & 70 & 1.06 & 74.1 \\
\hline Selada siomak & 80 & 0.75 & 59.7 \\
\hline Seledri & 30 & 2.06 & 61.7 \\
\hline Spinact & 330 & 1.20 & 396.1 \\
\hline Timun jepang & 40 & 0.34 & 13.4 \\
\hline Timun lokal & 30 & 2.78 & 83.3 \\
\hline Tomat buah & 70 & 0.04 & 2.8 \\
\hline Tomat cerry & 40 & 0.89 & 35.5 \\
\hline Wortel & 1270 & 1.59 & 2019.3 \\
\hline
\end{tabular}


Gandamanah, Desa Tugu Selatan, Cisarua, Bogor, Jawa Barat. Pemilihan lokasi dilakukan dengan secara sengaja (purposive) dengan mempertimbangkan bahwa Yayasan Bina Sarana Bakti adalah perusahaan agribisnis yang menghasilkan komoditi pertanian dengan sistem organik. Penelitian ini dilaksanakan pada bulan Maret - Mei 2015.

Penelitian ini menggunakan data cross section. Sumber data yang digunakan dalam penelitian ini adalah data primer dan data sekunder. Data primer dibutuhkan untuk menjawab tujuan penelitian, diperoleh langsung dari pengamatan lapangan terutama tekait bagian produksi dan pemasaran melalui wawancara menggunakan panduan kuesioner. Data sekunder yaitu data pencatatan laporan perusahaan di lapangan yang dianggap perlu dalam penelitian ini, literatur yang dianggap penting serta dokumen perusahaan yang relevan dengan penelitian. Pemilihan sampel dilakukan secara purposive sampling yaitu perusahaan sayuran organik (Yayasan Bina Sarana Bakti), dimana di dalam perusahaan tersebut terdapat 24 petani di divisi produksi.

Analisis yang dilakukan pada penelitian ini meliputi analisis kualitatif dan kuantitatif dengan mencari tingkat produksi optimal untuk memperoleh keuntungan maksimal perusahaan. Pengolahan data dilakukan dengan menggunakan program Microsoft Excel 2007 dan software LINDO (Linear Ineraktive Discrete Optimizer).

Analisis optimasi produksi dalam penelitian ini disajikan dalam model matematis berbentuk linear program- ming. Agar mempermudah proses perhitungan, dan mampu mendeskripsikan permasalahan di lapangan ke dalam model linear programming, maka desain penelitian yang digunakan adalah seluruh variabel keputusan dihitung pada luas lahan sayuran dalam $\mathrm{m}^{2} / \mathrm{satu}$ musim tanam. Hasil pengolahan dilakukan dengan tiga analisis yaitu analisis primal, analisis dual, dan analisis sensitivitas.

\section{Fungsi Tujuan}

$$
\text { Maksimumkan } \Pi=\sum_{i=1}^{n} c_{i} L_{i}
$$

Keterangan:

$\Pi$ : Nilai fungsi tujuan total laba kotor satu musim tanam (Rp)

$c_{i}$ : Kontribusi rata-rata laba kotor sayuran ke-i per $\mathrm{m}^{2}$ luas lahan $\left(\mathrm{Rp} / \mathrm{m}^{2}\right)$ dimana $i=1,2, \ldots, \mathrm{n}$

$\mathrm{L}_{\mathrm{i}}$ : Variabel luas lahan jenis sayuran ke-i $\left(\mathrm{m}^{2}\right) \quad(i=$ $1,2, \ldots, \mathrm{n})$

\section{Kendala Lahan}

$$
\sum_{i=1}^{n} L_{i} \leq K L
$$

Keterangan:

$\mathrm{L}_{\mathrm{i}}$ : Variabel luas lahan jenis sayuran ke- $i\left(\mathrm{~m}^{2}\right)(\mathrm{i}=$ $1,2, \ldots, \mathrm{n})$

$\mathrm{KL}$ : Total ketersediaan lahan $\left(\mathrm{m}^{2}\right)$

\section{Kendala Tenaga Kerja}

$$
\sum_{i=1}^{n} T K_{i} L_{i} \leq T T K
$$

Keterangan:

$\mathrm{TK}_{\mathrm{i}}$ : Tenaga kerja per $\mathrm{m}^{2}$ luas lahan sayuran ke-i $\left(\mathrm{HOK} / \mathrm{m}^{2}\right)$

$\mathrm{L}_{\mathrm{i}} \quad$ : Variabel luas lahan jenis sayuran ke-i $\left(\mathrm{m}^{2}\right)(\mathrm{i}=$ $1,2, \ldots, n)$

TTK : Total ketersediaan tenaga kerja (HOK)

\section{Kendala Modal}

Keterangan:

$$
\sum_{i=1}^{n} M_{i} L_{i} \leq T M
$$

$\mathrm{M}_{\mathrm{i}}$ : Rata-rata modal digunakan per $\mathrm{m}^{2}$ sayuran ke-i $\left(\mathrm{Rp} / \mathrm{m}^{2}\right.$ ) 
$\mathrm{L}_{\mathrm{i}}$ : Variabel luas lahan jenis sayuran ke- $i\left(\mathrm{~m}^{2}\right)(\mathrm{i}=$ $1,2, \ldots, \mathrm{n})$

TM : Total modal dianggarkan keseluruhan jenis sayuran dalam satu periode tanam (Rp)

\section{Kendala Kemampuan Produksi}

$$
\operatorname{Pr} L_{i} \leq T D_{i}
$$

Keterangan:

Pr` : Produktivitas lahan jenis sayuran ke-i per $\mathrm{m}^{2}(\mathrm{~kg} /$ $\mathrm{m}^{2}$ )

$\mathrm{L}_{\mathrm{i}}$ : Variabel luas lahan jenis sayuran ke- $i\left(\mathrm{~m}^{2}\right)(\mathrm{i}=$ $1,2, \ldots, \mathrm{n})$

$\mathrm{TD}_{\mathrm{i}}$ : Total permintaan sayuran ke- $I$ terhadap perusahaan $(\mathrm{kg})$

\section{HASIL DAN PEMBAHASAN}

\section{Analisis Optimasi Produksi}

Analisis primal linear programming menunjukkan kombinasi jenis produk optimal yang memberikan kontribusi laba yang maksimal bagi perusahaan. Dalam penelitian ini, analisis primal yang dianalisis menunjukkan informasi tentang kombinasi tingkat produksi sayur yang diproduksi secara optimal agar Yayasan Bina Sarana Bakti mampu memperoleh keuntungan yang maksimal berdasarkan produktivitas lahannnya.

Berdasarkan hasil analisis primal dalam kondisi optimal penggunaan lahan perusahaan maka dapat ditentukan kombinasi produksi dalam bentuk output sayuran organik sesuai produktivitas lahan setiap jenis sayur yang dimiliki oleh perusahaan. Gambaran optimal lahan menjadi informasi bagi perusahaan untuk pengalokasian perencanaan lahan kedepannya agar mampu berproduksi optimal sedangkan gambaran optimal produk sayur merupakan informasi terhadap hasil produksi yang diperoleh nantinya apabila perusahaan mengikuti syarat penggunaan lahan optimalnya.

Informasi gambar berikut menjelaskan bahwa hasil analisis optimal memberikan perubahan yang berbedabeda setiap jenis sayur organik sesuai produkstivitas lahan masing-masing tanaman yang dimiliki. Perubahan jumlah produksi yang cukup besar dari kondisi aktual pada kondisi optimal memberikan gambaran bagi perusahaan akan peluang produksi yang lebih tinggi lagi untuk mencapai keadaan optimal. Hasil menunjukkan bahwa jumlah produksi sayur organik kondisi aktual sebesar

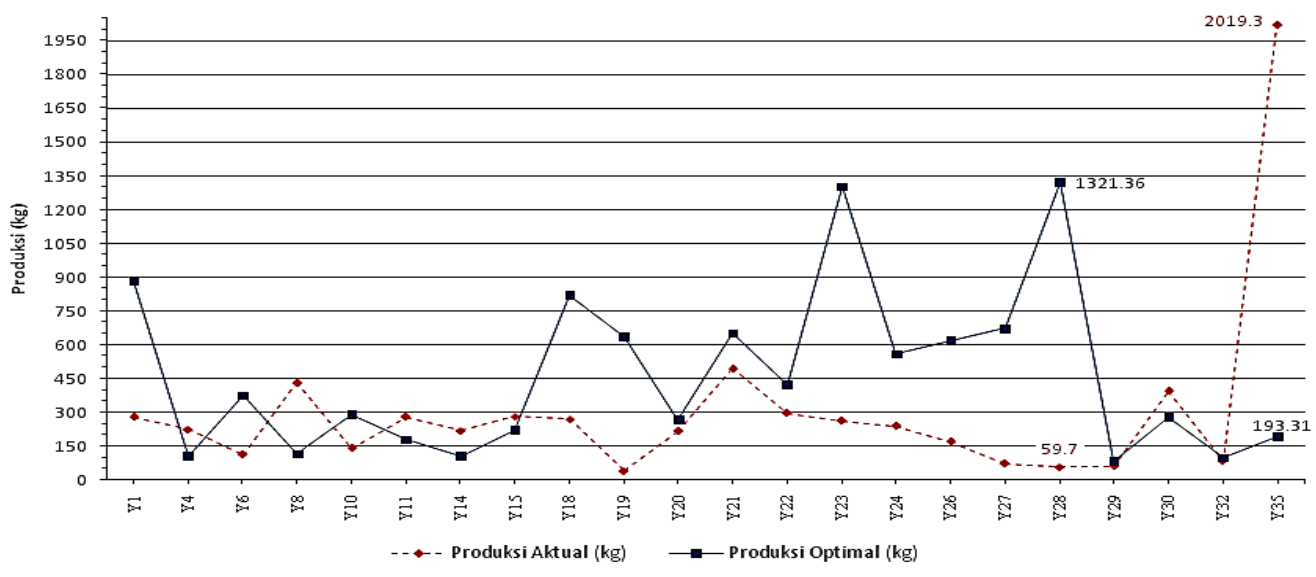

Gambar 1. Produksi Sayur Organik Kondisi Aktual dan Optimal Satuan (kg) 
7110,1 kg sedangkan kondisi optimal sebesar 10219,11 kg. Perubahan produksi untuk mencapai kondisi optimal sebesar 43,72 persen. Peningkatan jumlah produksi tersebut karena adanya pengaruh dari penambahan luas lahan yang digunakan pada keadaan optimal sehingga mempengaruhi peningkatan produksi dari produktivitas lahan setiap sayuran organik. Peningkatan jumlah produksi juga perlu disertai perluasan pasar, sesuai pendapat (Maudi, 2011) bahwa adanya potensi peningkatan produksi sayuran organik perlu didukung dengan adanya perluasan pasar sehingga produk yang dihasilkan dapat terjual dan menghasilkan keuntungan yang lebih tinggi.

Peningkatan produksi terbesar pada jenis sayuran selada siomak mencapai $1.321,36 \mathrm{~kg}$ dengan penambahan produksi 1261,66 kg disamping itu terjadi selisih yang besar pada jenis sayuran wortel berkurang hingga 193,31 kg dengan pengurangan produksi 1.825,9 kg.
Artinya kondisi optimal tidak mengharuskan semua sayuran mengalami peningkatan produksi namun juga terjadi pengurangan produksi. Hal tersebut disebabkan pengaruh efisiensi sumberdaya setiap tanaman berbeda dan potensi keuntungannya juga berbeda. Hal ini sejalan dengan penelitian (Astuti, 2007) menyatakan bahwa jumlah tanaman yang memiliki potensi keuntungan yang tinggi maka jumlahnya juga akan lebih banyak pada kondisi optimal.

Analisis reduced cost menunjukan informasi tentang besarnya aktivitas yang tidak termasuk ke dalam perencanaan optimal tetapi dapat mempengaruhi nilai fungsi tujuan sebesar nilai reduced cost tersebut. Reduced cost menunjukkan bahwa apabila decision variabel yaitu luasan lahan produksi tiap jenis sayur dalam satuan $\mathrm{m}^{2}$ dipaksakan untuk dilaksanakan, maka fungsi tujuan akan menurun sebesar reduced cost.

Berdasarkan uraian berikut menunjukkan bahwa dalam kondisi optimal

Tabel 2. Kombinasi Produk Sayuran Organik yang Tidak Diproduksi

\begin{tabular}{clr}
\hline Variabel & \multicolumn{1}{c}{ Jenis Sayur } & Reduced Cost \\
\hline $\mathrm{Y}_{2}$ & Bawang Daun & 3083,59 \\
$\mathrm{Y}_{3}$ & Bayam Merah & 2313,73 \\
$\mathrm{Y}_{5}$ & Brocoli & 1392,00 \\
$\mathrm{Y}_{7}$ & Cabe Rawit & 10584,41 \\
$\mathrm{Y}_{9}$ & Endive & 794,78 \\
$\mathrm{Y}_{12}$ & Kacang Merah & 3801,65 \\
$\mathrm{Y}_{13}$ & Kacang Tanah & 6558,81 \\
$\mathrm{Y}_{16}$ & Kapri muda & 10208,18 \\
$\mathrm{Y}_{17}$ & Kapri polong & 25881,56 \\
$\mathrm{Y}_{25}$ & Selada head & 1967,90 \\
$\mathrm{Y}_{31}$ & Timun jepang & 17065,03 \\
$\mathrm{Y}_{33}$ & Tomat buah & 13821,83 \\
$\mathrm{Y}_{34}$ & Tomat cerry & 17851,84 \\
\hline
\end{tabular}


tidak mengharuskan perusahaan memproduksi jenis sayur organik secara keseluruhan. Diantaranya terdapat 13 crop sayur organik yang memiliki nilai reduced cost atau sebesar 37 persen dari kombinasi jenis sayur aktual tidak diproduksi pada kondisi optimal dan tidak termasuk ke dalam perencanaan produksi, artinya apabila perusahaan mengambil keputusan memproduksi sebesar satu $\mathrm{m}^{2}$ jenis tanaman tersebut, maka keuntungan perusahaan berkurang sebesar nilai reduced costnya. Nilai reduced cost terbesar terdapat pada tanaman kapri polong dalam hal ini menunjukkan bahwa apabila menambah lahan produksi kapri polong sebesar satu $\mathrm{m}^{2}$ dari kondisi optimal maka akan mengurangi keuntungan sebesar Rp 25.881. Gam- baran nilai reduced cost serta kombinasi tanamannya merupakan gambaran bagi perusahaan terhadap hasil analisis yang telah dilakukan.

Berdasarkan hasil analisis primal pada optimasi produksi juga akan terlihat kombinasi sayur organik dan luas lahan optimalnya. Kondisi optimal menunjukkan perusahaan berproduksi pada 22 crop sayur organik dengan total penggunaan lahan sebesar 10.064,38 $\mathrm{m}^{2}$ dari kondisi aktual lahan sebesar $11.190 \mathrm{~m}^{2}$ dengan produksi aktual 35 crop sayur atau sebesar 89,94 persen pemakaian lahan pada kondisi optimal sehingga terdapat surplus sumberdaya lahan sebesar 10,06 persen. Menurut pendapat (Suratiyah, 2006), bahwa faktor produksi berupa lahan perlu dikoordinir dan diper-

Tabel 3. Kombinasi Jenis Sayur Organik dan Nilai Optimal Lahan Produksi (m²)

\begin{tabular}{clr}
\hline Variabel Lahan & \multicolumn{1}{c}{ Jenis Sayur } & Lahan Optimal ( $\mathbf{m}^{\mathbf{2}} \mathbf{)}$ \\
\hline $\mathrm{L}_{1}$ & Bayam Hijau & $1.047,62$ \\
$\mathrm{~L}_{4}$ & Bit & 56,08 \\
$\mathrm{~L}_{6}$ & Buncis & $63, .9$ \\
$\mathrm{~L}_{8}$ & Caysim & 45,67 \\
$\mathrm{~L}_{10}$ & Jagung baby & 515,79 \\
$\mathrm{~L}_{11}$ & Jagung Manis & 179 \\
$\mathrm{~L}_{14}$ & Kailan & 73,97 \\
$\mathrm{~L}_{15}$ & Kangkung & 211,43 \\
$\mathrm{~L}_{18}$ & Kol bulat putih & 573,43 \\
$\mathrm{~L}_{19}$ & Kol bunga & $1.056,96$ \\
$\mathrm{~L}_{20}$ & Lobak & 49,54 \\
$\mathrm{~L}_{21}$ & Pakcoi hijau & 342,41 \\
$\mathrm{~L}_{22}$ & Pakcoi putih & 185,96 \\
$\mathrm{~L}_{23}$ & Petsai nagaoka & $1.489,66$ \\
$\mathrm{~L}_{24}$ & Selada cos & 328,65 \\
$\mathrm{~L}_{26}$ & Selada keriting & 436,62 \\
$\mathrm{~L}_{27}$ & Selada merah & 635,85 \\
$\mathrm{~L}_{28}$ & Selada siomak & $1.770,67$ \\
$\mathrm{~L}_{29}$ & Seledri & 40,29 \\
$\mathrm{~L}_{30}$ & Spinact & 233,33 \\
$\mathrm{~L}_{32}$ & Timun local & 35,97 \\
$\mathrm{~L}_{35}$ & Wortel & 121,58 \\
\hline & Total & $10.064,38$ \\
\hline
\end{tabular}




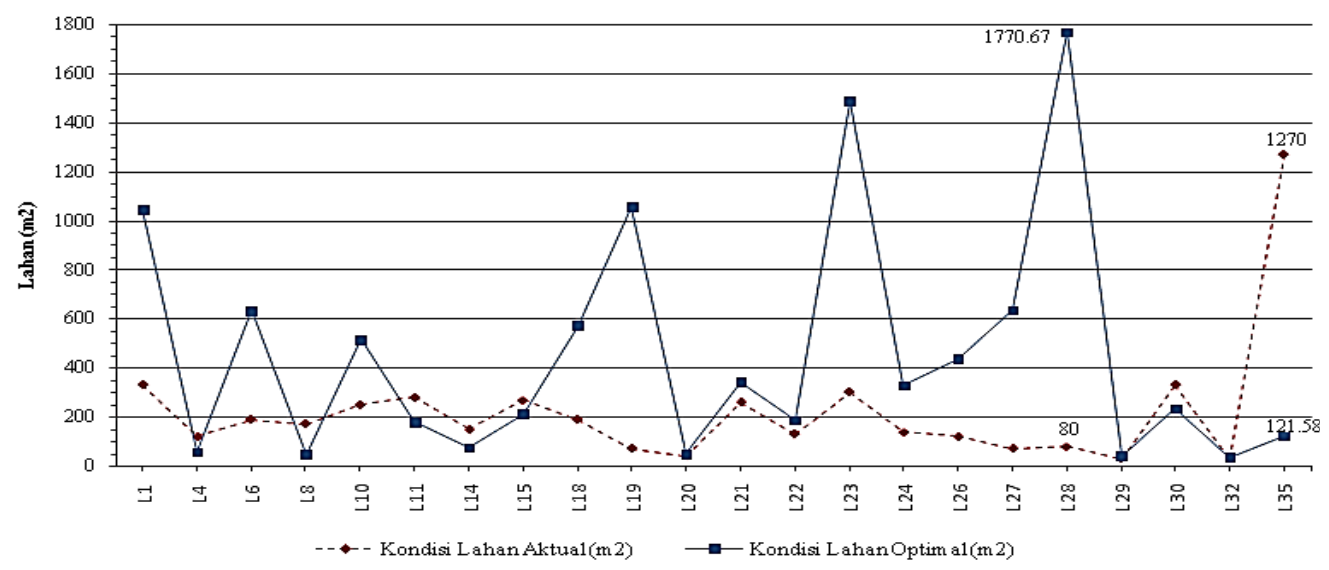

\section{Gambar 2. Perbandingan Lahan Produksi Aktual dan Optimal dalam Satuan} $\left(\mathbf{m}^{2}\right)$

hitungkan dengan baik sebagai modal utama usahatani sehingga memberikan manfaat yang sebaik-baiknya dan mampu mencapai keuntungan pada usahatani yang dilakukan.

Informasi berikut menjelaskan bahwa kondisi lahan produksi yang tersedia sebagai kendala produksi merupakan kendala bukan pembatas. Tingkat perubahan jumlah luasan lahan yang berbeda-beda tersebut menjadi gambaran perusahaan dalam mengambil keputusan untuk memproduksi sayuran organik dengan keterbatasan sumberdaya yang ada. Perencanaan produksi perusahaan akan lebih fokus pada jenis sayuran tersebut pada musim tanam pertama untuk ditingkatkan penggunaan lahannya atas dasar memaksimalkan keuntungan. Adapun luasan lahan untuk masingmasing sayuran organik yang diproduksi pada kondisi optimal perusahaan tersaji pada Tabel 3.

Perubahan tingkat produksi optimal tentunya dipengaruhi oleh perubahan penggunaan sumberdaya lahan yang merupakan hasil dari analisis optimasi. Hasil menunjukkan bahwa terdapat peningkatan penggunaan jumlah lahan untuk jenis sayur optimal tersebut sebesar $5.244,38 \mathrm{~m}^{2}$ atau sebesar 108,80 persen dengan total lahan optimal 10.064,38 $\mathrm{m}^{2}$. Jenis sayur mengalami peningkatan pemakaian lahan terbesar pada selada siomak dan penurunan pemakaian terbesar juga lahan pada sayur wortel.

Sayuran organik terdiri dari 35 crop yang diproduksi oleh perusahaan terdiri dari kombinasi empat macam usia tanaman yaitu tanaman 6,8,10, dan 12 minggu. Semua jenis tanaman tersebut diproduksi kedalam satu areal lahan seluas $11190 \mathrm{~m}^{2}$ dengan 10 plot area. Adapun perbandingan pola tanam aktual dan optimal sayuran organik yang diproduksi Yayasan Bina Sarana Bakti berdasarkan dimensi waktu tanam dan panen tersaji pada Tabel 4 .

Perubahan jumlah komoditi sayur organik yang diproduksi dari kondisi aktual 35 crop menjadi 22 crop, serta luas lahan produksi yang digunakan 
Tabel 4. Perbandingan Pola Tanam Aktual dan Optimal Berdasarkan Usia Tanaman $\left(\mathrm{m}^{2}\right)$

\begin{tabular}{|c|c|}
\hline $\begin{array}{c}\text { Usia } \\
\text { Tanaman }\end{array}$ & Kombinasi Tanaman Aktual/Optimal \\
\hline 6 minggu & $\begin{array}{l}\text { Pola tanam aktual } \\
\text { Bayam hijau+bayam merah+caysim+endive+kalian+kangkung+pakcoi } \\
\text { hijau+pakcoi putih+selada cos+selada head+selada keriting+selada } \\
\text { merah+selada siomak+seledri+spinact } \\
\text { Pola tanam optimal } \\
\text { Bayam hijau +caysim+kalian+kangkung+pakcoi hijau+pakcoi } \\
\text { putih+selada cos +selada keriting+selada merah+selada } \\
\text { siomak+seledri+spinact }\end{array}$ \\
\hline 8 minggu & $\begin{array}{l}\text { Pola tanam aktual } \\
\text { Bawang daun }+ \text { bit }+ \text { kapri muda }+ \text { kol bunga }+ \text { lobak }+ \text { petsai nagaoka }+ \\
\text { timun jepang + timun lokal } \\
\text { Pola tanam optimal } \\
\text { Bit }+ \text { kol bunga }+ \text { lobak }+ \text { petsai nagaoka }\end{array}$ \\
\hline 10 minggu & $\begin{array}{l}\text { Pola tanam aktual } \\
\text { Brocoli+ buncis+ jagung baby+kapri polong+ kol bulat putih+ tomat } \\
\text { buah } \\
\text { Pola tanam optimal } \\
\text { Buncis + jagung baby + kol bulat putih }\end{array}$ \\
\hline 12 minggu & $\begin{array}{l}\text { Pola tanam aktual } \\
\text { Cabe rawit + jagung manis }+ \text { kacang merah }+ \text { kacang tanah }+ \text { tomat cerri } \\
+ \text { wortel } \\
\text { Pola tanam optimal } \\
\text { Jagung manis + wortel }\end{array}$ \\
\hline
\end{tabular}

mengalami pengurangan dari keadaan aktual $11.190 \mathrm{~m}^{2}$ menjadi $10.064 \mathrm{~m}^{2}$ sehingga dari kondisi optimal tersebut berdampak pada keuntungan perusahaan dengan adanya perubahan dari kondisi aktual sebesar Rp 87.318.222 dan kondisi optimalnya menjadi Rp 137.846.052 atau dengan peningkatan keuntungan sebesar 57,86 persen. Peningkatan keuntungan tersebut tergolong tinggi dalam satu musim tanam karena didukung keadaan harga jual sayur organik perusahaan yang cukup tinggi dengan penggunaan sumberdaya yang efisien pada keadaan optimal. Hasil tersebut membuktikan bahwa pertanian organik memberikan keuntungan yang cukup besar. Hal ini sesuai dengan penelitian (Sugino, 2010)

Tabel 5. Tingkat Keuntungan Aktual dan Optimal YBSB

\begin{tabular}{cccr}
\hline $\begin{array}{c}\text { Kondisi } \\
\text { Produksi }\end{array}$ & Aktivitas Produksi & $\begin{array}{c}\text { Total Penggunaan } \\
\left.\text { Lahan } \mathbf{( m}^{\mathbf{2}}\right)\end{array}$ & Keuntungan (Rp) \\
\hline Aktual & Produksi 35 crop sayur & 11.190 & 87.318 .222 \\
Optimal & Produksi 22 crop sayur & 10.064 & 137.846 .052 \\
\hline \multicolumn{3}{c}{ Kenaikan Keuntungan (Rp) } & 50.527 .830 \\
\hline & Persentase Perubahan (\%) & $57,86 \%$ \\
\hline
\end{tabular}


bahwa rata-rata harga produk organik adalah dua kali lipat harga konvensional, sedangkan biaya produksi organik adalah setengah biaya produksi konvensional sehingga pertanian organik memberikan keuntungan besar dan berpengaruh nyata terhadap pendapatan produsen organik. Keuntungan yang diperoleh cukup tinggi dengan skala usahatani yang juga cukup besar, sesuai pendapat (Chaerunnisa, 2007) bahwa tingkat keuntungan pada usahatani sayuran skala kecil dan skala besar sangatlah berbeda.

Gambar 3 menjelaskan uraian keuntungan kotor yang diperoleh Yayasan Bina Sarana Bakti dari kombinasi jenis sayuran organik pada kondisi optimal. Hasil dari analisis menunjukkan bahwa terdapat perbedaan tingkat keuntungan dari setiap sayuran organik yang diproduksi.

Hasil menunjukkan bahwa nilai keuntungan terbesar yang diperoleh ada pada sayuran selada siomak mencapai Rp 17.818.305 dengan total produksi
1.321,36 kg sedangkan keuntungan terendah dalam kondisi optimal pada jenis sayur caysim Rp 1.266.754 dengan total produksi 115,84 kg. Perubahan keuntungan dari tiap-tiap tanaman dipengaruhi jumlah produksi optimalnya dan pengaruh dari penggunaan lahan optimal sesuai produktivitas masingmasing serta harga jualnya. Sesuai hasil penelitian (Khalik, 2013) dengan tema optimasi pola tanam sayuran selada dan sawi bahwa umumnya tanaman yang terpilih dalam skema optimal karena harga jual yang tinggi dibanding tanaman lainnya.

Analisis dual memberikan informasi tentang penilaian terhadap sumberdaya yang digunakan dalam model linear programming yang ditunjukkan oleh nilai slack atau surplus dimana digunakan untuk mengetahui tingkat penggunaan sumberdaya yang menghasilkan solusi terbaik atau optimal. Slack/surplus sama dengan nol menunjukkan bahwa sumber daya bersifat terbatas termasuk dalam

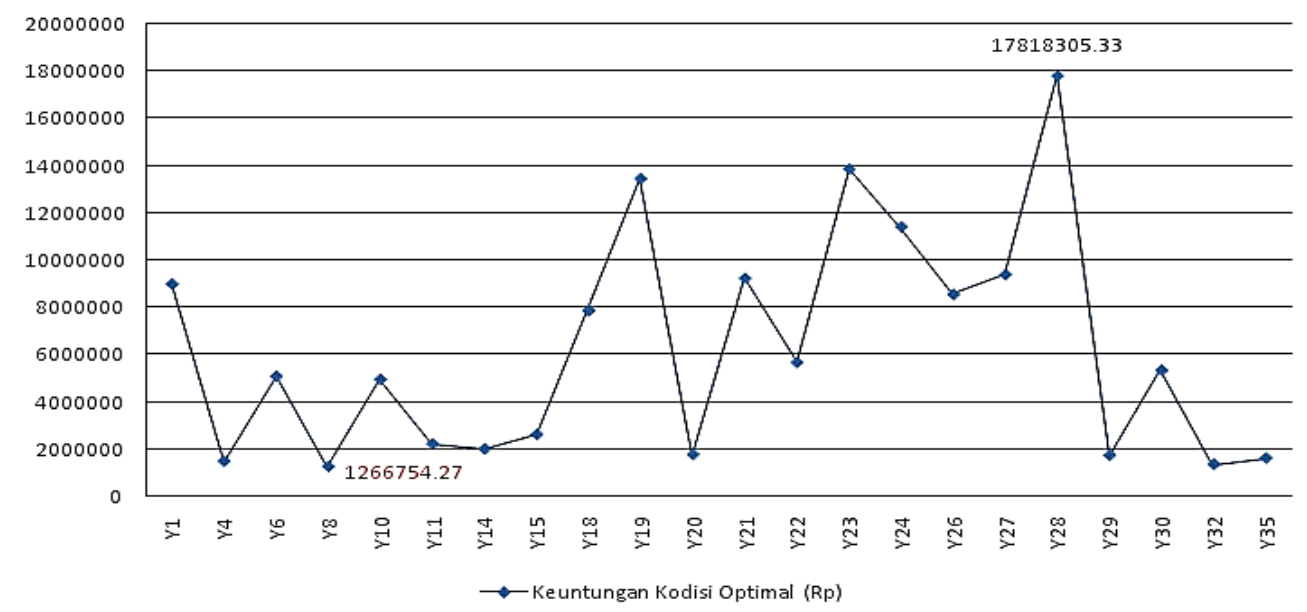

Gambar 3. Keuntungan Produksi Optimal Sayur Organik Yayasan Bina Sarana Bakti (Rp) 
Tabel 6. Analisis Dual Price Penggunaan Sumberdaya Yayasan Bina Sarana Bakti

\begin{tabular}{clrr} 
No & \multicolumn{1}{c}{ Jenis Kendala } & Slack/surplus & Dual Price (Rp) \\
\hline 1 & Kendala Lahan $\left(\mathrm{m}^{2}\right)$ & $1.125,62$ & 0 \\
2 & Kendala Tenaga Kerja (HOK) & 0 & $19.721,05$ \\
3 & Kendala Modal (Rp) & 0 & 3.07 \\
4 & Kemampuan Produksi (kg) & 0 & $4.437,92$ \\
& Y $_{1}$ (Bayam hijau) & 102 & 0 \\
\hline
\end{tabular}

sumber daya aktif. Nilai dual price pada sumber daya terbatas dalam penelitian ini menunjukkan bahwa setiap penambahan sumber daya sebesar satu satuan akan meningkatkan nilai fungsi tujuan sebesar nilai dual pricenya. Sumber daya dengan nilai dual price sama dengan nol menunjukkan bahwa sumber daya tersebut berstatus kendala tidak aktif atau berlebih, dimana penambahan atau pengurangan ketersediaan pada sumber daya tersebut tidak akan mempengaruhi nilai pada fungsi tujuan.

Tabel 6 menunjukkan bahwa berdasarkan hasil analisis dual price nya maka yang termasuk kedalam kendala sumberdaya pembatas adalah sumber daya tenaga kerja dan modal dimana jika terjadi kenaikan ketersediaan sumberdaya sebesar satu satuan pada tenaga kerja dalam bentuk HOK maka akan meningkatkan keuntungan sebesar Rp 19.721 dan jika terjadi kenaikan ketersediaan sumberdaya modal sebesar satu satuan (Rp) maka akan meningkatkan keuntungan sebesar Rp 3,07 hal tersebut berimplikasi bahwa penambahan resource atau seumber daya yang paling utama ditingkatkan adalah jumlah tenaga kerja kemudian disusul penambahan modal, artinya sebagai tujuan perusahaan untuk meningkatkan keuntungan maka keputusan yang tepat adalah penambahan jumlah tenaga kerja dimana satu HOK mampu menambah keuntungan sebesar Rp 19.721.

Disamping itu terdapat kendala sumberdaya lahan yang memiliki slack/surplus sebesar 1.125,62 dan nilai dual price nya sama dengan nol. Artinya terdapat luas lahan sebesar 1.125,62 $\mathrm{m}^{2}$ termasuk kategori tidak digunakan oleh perusahaan dan menunjukkan bahwa sumberdaya lahan berstatus kendala tidak aktif atau berlebih dimana apabila terjadi penambahan atau pengurangan lahan tidak akan mengurangi nilai pada fungsi tujuan. Sehingga lahan yang dikaji dalam penelitian ini karena memiliki status berlebih ditandai dengan adanya nilai slack/surplus nya maka implikasi dari informasi ini adalah sebaiknya perusahaan mengurangi penggunaan lahan dalam produksinya dan seharusnya perusahaan mengurangi pemakaian lahan sebesar nilai slack/surplusnya yaitu 1.125,62 $\mathrm{m}^{2}$ atau pengambilan keputusan lain sebagai alternatif tindakan terhadap kondisi optimal tersebut adalah lahan yang berlebih dapat digunakan untuk disewakan terhadap petani plasma sebagai bentuk kontrak yang berjalan atau pun pemanfaatan jenis tanaman lain seperti tanaman herbal, tanaman bunga 
yang juga menjadi tanaman milik perusahaan yang sedang dijalankan.

Disamping itu analisis dual pada jenis kendala lain yaitu salah satunya pada jenis sayuran bayam hijau $\left(\mathrm{Y}_{1}\right)$ kendala kemampuan produksi perusahaan dimana produksi sayur $\mathrm{Y}_{1}$ apabila permintaannya bertambah 1 (satu) $\mathrm{kg}$ dan perusahaan mampu memenuhi permintaan tersebut maka keuntungan bertambah sebesar Rp 4.437,92, oleh karena itu pada bagian kendala ini, jenis sayuran yang memiliki nilai dual price adalah kendala pembatas bagi perusahaan, namun jenis sayuran yang justru memiliki nilai slack/surplus seperti bawang daun $\left(\mathrm{Y}_{2}\right)$ merupakan suatu kendala tidak aktif atau berlebih dimana apabila terjadi penambahan atau pengurangan permintaannya tidak akan mengurangi nilai pada keuntungan perusahaan sehingga tidak termasuk kategori produksi optimal.

\section{Analisis Sensitivitas}

Analisis sensitivitas dalam penelitian ini diperlukan untuk mengetahui sejauh mana hasil optimal dapat diterapkan apabila terjadi perubahan terhadap model. Pengaruh perubahan dapat dilihat dari selang kepekaan yang terdiri dari batas minimum dan batas maksimum yang diperoleh dari hasil analisis. Analisis sensitivitas dilihat dari nilai koefisien fungsi tujuan dan ruas kanan kendala yang terdapat pada penelitian sehingga akan terlihat tingkat kepekaan koefisien fungsi tujuannya dan ruas kanan kendala.

Selang kepekaan nilai koefisien fungsi tujuan yang memiliki batas minimum:

$$
\begin{array}{lll}
4852,67<\mathrm{C}_{1}<\infty & \multicolumn{1}{l}{10350,48<\mathrm{C}_{4}<\infty} \\
5910,51<\mathrm{C}_{10}<\infty & 8408,5 \quad<\mathrm{C}_{11}<\infty \\
8390,89<\mathrm{C}_{18}<\infty & 22262,17< & <\mathrm{C}_{20}< \\
& \infty & \\
5785,12<\mathrm{C}_{23}<\infty & 6812,32< & <\mathrm{C}_{24}<\infty \\
8437,83<\mathrm{C}_{28}<\infty & 18506,03 & <\mathrm{C}_{29}< \\
& \infty & \\
6939,67<\mathrm{C}_{6}<\infty & 7155,19<\mathrm{C}_{8}<\infty \\
7158,88<\mathrm{C}_{14}<\infty & 7207,72<\mathrm{C}_{15}<\infty \\
6658,55<\mathrm{C}_{21}<\infty & 7857,73<\mathrm{C}_{22}<\infty \\
7044,38<\mathrm{C}_{26}<\infty & 10299,24< & <\mathrm{C}_{27}< \\
& \infty & \\
6535,7<\mathrm{C}_{30}<\infty & 24423,42< & <\mathrm{C}_{32}< \\
& \infty &
\end{array}
$$

Selang kepekaan nilai koefisien fungsi tujuan yang memiliki batas maksimum:

$$
\begin{aligned}
& \infty \quad<\mathrm{C}_{2} \quad<\infty<\mathrm{C}_{3}<4458,49 \\
& \text { 23966,08 } \\
& \infty \quad<\mathrm{C}_{9} \quad<\infty \quad<\mathrm{C}_{12}< \\
& \text { 23436,66 10198,67 } \\
& \infty \quad<\mathrm{C}_{17}<\infty<\mathrm{C}_{25}<8916,72 \\
& \text { 31655,08 } \\
& \infty \quad<\mathrm{C}_{34}<\infty \quad<\mathrm{C}_{35}< \\
& \text { 26454,34 19878,33 } \\
& \infty<\mathrm{C}_{5}<6512,17 \quad \infty<\mathrm{C}_{7}<21694,05
\end{aligned}
$$

Tabel 7. Analisis Sensitivitas Nilai Ruas Kanan Kendala

\begin{tabular}{lrrr}
\hline \multicolumn{1}{c}{ Kendala } & Current Coef & Allowable Increase & Allowable Decrease \\
\hline Lahan $\left(\mathrm{m}^{2}\right)$ & 11.190 & Infinity & $1.125,62$ \\
Tenaga Kerja (HOK) & $2.289,60$ & 45.76 & 485.13 \\
Modal (Rp) & 11.459 .928 & 4.932 .807 & $487.467,56$ \\
\hline
\end{tabular}




$$
\begin{array}{llll}
\infty<\mathrm{C}_{13}<7115,77 & \infty & <\mathrm{C}_{16}< \\
\infty & & 26372,85 & \\
21014,05 & <\mathrm{C}_{31}< & \infty & <\mathrm{C}_{33}< \\
& & 13661,46 &
\end{array}
$$

Selang kepekaan nilai koefisien fungsi tujuan dengan batas minimum dan maksimum:

$$
12277,96<\mathrm{C}_{19}<15107,43
$$

Analisis sensitivitas dilakukan guna mengetahui kepekaan perubahan sumberdaya produksi dengan tidak mengubah pendapatan optimal usahatani tersebut (Puspitasari, 2013). Berdasarkan hasil analisis RHS di atas menunjukkan bahwa pada sumberdaya tenaga kerja mempunyai koefisien nilai saat ini sebesar 2.289,6 kenaikan diperkenangkan sebesar 45,76 dan penurunan diperkenangkan sebesar 485,13, maka kisaran optimasi sumberdaya tenaga kerja adalah $1.804,47<\mathrm{TK}<2.335,36$. Kisaran ini memberikan informasi bahwa ketersediaan HOK tenaga kerja diperbolehkan naik maksimum 2.335,36 HOK dan turun sampai minimum 1.804,47 HOK. Jadi apabila perusahaan menerapkan $\mathrm{HOK}$ antara range tersebut di atas maka nilai dual dari sumber daya tenaga kerja adalah tetap Rp 19.721.

Sementara itu hasil analisis sensitivitas sumberdaya lahan tidak memiliki batas kenaikan (infinity) dimana apabila penggunaan sumberdaya lahan terus ditingkatkan sampai berapa pun maka nilai dual sumberdaya lahan tetap nol karena lahan merupakan kendala bukan pembatas, artinya perusahaan tidak perlu lagi melakukan peningkatan produksi, apabila terjadi peningkatan lahan produksi berapapun besarnya maka tidak akan mempengaruhi keuntungan yang diterima, adapun batas bawahnya hingga $10.064 \mathrm{~m}^{2}$.

Perubahan kendala modal diperbolehkan pada kisaran $10.972 .461<\mathrm{M}$ $<16.392 .735$, menurut (Wicaksono, 2006) bahwa sumberdaya yang merupakan kendala dalam usahatani menjadi hal utama yang perlu diperhatikan. Sementara kendala kemampuan produksi perusahaan, analisis sensitivitasnya menunjukkan bahwa terdapat batas minimal produksi yang perlu diperhatikan perusahaan agar tetap dalam kondisi optimal dan terdapat beberapa kombinasi tanaman yang memiliki batas maksimum yang juga menjadi perhatian perusahaan dalam produksinya.

\section{Analisis Post Optimalitas}

Analisis pengaruh perubahan ketersediaan sumberdaya dan keuntungan terhadap kondisi produksi optimal digunakan anilisis post optimalitas. Analisis post optimalitas dalam hal ini dilakukan untuk mencari kemungkinankemungkinan dan besarnya perubahan pada solusi optimal atau nilai dual jika terjadi perubahan pada koefisien nilai fungsi tujuan dan nilai ruas kanan kendala diluar batas perubahan yang diperbolehkan dalam solusi optimal sebelumnya. Pada analisis post optimalitas dalam penelitian ini digunakan perubahan harga produk sayur organik dan perubahan harga input yang digunakan. Perubahan harga produk sayur organik dianalisis dari adanya penurunan harga sayur organik sebesar 10 persen sehingga mem- 
pengaruhi kondisi produksi optimal perusahaan. Sedangkan perubahan pada harga input dianalisis dari adanya peningkatan harga input pupuk organik dan bibit organik sebesar 10 persen. Perubahan sebesar sepuluh persen baik dari penurunan harga output maupun peningkatan harga input atas dasar kondisi real perusahaan yang terkadang mengalami perubahan harga output saat kondisi tertentu dan perubahan harga pupuk maupun bibit yang cenderung mendekati 10 persen dari keadaan awalnya.

Skenario post optimal dengan menurunkan harga output dan menaikkan harga input pupuk maupun bibit tersebut diharapkan dapat mengetahui jumlah dan jenis tanaman sayuran organik yang dapat menghasilkan keuntungan maksimal serta penggunaan sumberdaya optimal. Selain itu diharapkan dapat mengetahui perubahan tingkat keuntungan yang diperoleh dalam kondisi optimalnya pada saat perusahaan tersebut mengalami perubahan pada skenario tersebut.

Pada kondisi post optimal pertama, yaitu penurunan harga produk sayur organik 10 persen, maka hasil post optimalitas diperoleh bahwa terjadi penurunan keuntungan sebesar 10,83 persen dari keadaan optimal semula. Namun dampaknya terhadap jumlah produksi optimalnya adalah tetap dimana pada saat kondisi optimal tidak mengalami perubahan jenis sayur dan jumlah produksi optimalnya. Pada analisis sumberdaya optimalnya juga tidak mengalami perbedaan besar terhadap kondisi optimal awalnya dimana sumberdaya yang digunakan juga terdapat surplus pada lahan dan merupakan kendala bukan pembatas sedangkan untuk modal dan tenaga kerja merupakan kendala pembatas namun terjadi perbedaan nilai dual pada sumberdaya tenaga kerja dan modal.

Skenario post optimal kedua yaitu dengan menaikkan harga pupuk organik dan bibit sebesar 10 persen, hasil post optimalnya diperoleh bahwa terjadi penurunan keuntungan hanya sebesar 1,13 persen. Hasil tersebut menunjukkan terjadi perbedaan selisih keuntungan pada kondisi perubahan harga output. Kanaikan harga input menurunkan keuntungan dari kondisi optimal awal yang jauh lebih kecil dibandingkan penurunan harga output yang masingmasing perubahannya sebesar 10 persen. Dampaknya terhadap jumlah produksi optimalnya terdapat beberapa perbedaan yaitu pada jenis sayur kol bunga dan wortel dimana terjadi peningkatan jumlah produksi pada kol bunga dan penurunan produksi pada wortel. Sementara untuk analisis sumberdaya optimalnya juga terdapat beberapa perbedaan diantaranya sumberdaya lahan terjadi kelebihan surplus sebesar $1.183 \mathrm{~m}^{2}$ dimana jumlah tersebut lebih besar dibanding nilai surplus kondisi optimal awal yaitu sebesar $1.125 \mathrm{~m}^{2}$ sedangkan untuk nilai dual tenaga kerja dan modal juga terjadi perubahan.

Kondisi post optimal skenario ketiga dimana terjadi penurunan harga output dan kenaikan harga input masing-masing sebesar 10 persen juga dianalisis untuk mengetahui perubahan terhadap keuntungan, tingkat produksi optimal, dan penggunaan sumberdaya optimal. 
Tabel 8. Analisis Post Optimalitas terhadap Perubahan Keuntungan

\begin{tabular}{clcc}
\hline $\begin{array}{c}\text { Skenario } \\
\text { Perubahan }\end{array}$ & \multicolumn{1}{c}{$\begin{array}{c}\text { Analisis Post } \\
\text { Optimalitas }\end{array}$} & $\begin{array}{c}\text { Keuntungan } \\
\text { (Rp) }\end{array}$ & $\begin{array}{c}\text { Selisih } \\
\text { keuntunga } \\
\text { n (\%) }\end{array}$ \\
\hline $\begin{array}{c}\text { Post Optimal } \\
\text { Skenario 1 }\end{array}$ & Penurunan harga output 10\% & 122.915 .700 & 10,83 \\
Post Optimal \\
Skenario II & $\begin{array}{l}\text { Peningkatan harga input (pupuk } \\
\text { organik, bibit) 10\% }\end{array}$ & 136.280 .000 & 1,13 \\
Post Optimal & $\begin{array}{l}\text { Penurunan harga output 10\% dan } \\
\text { peningkatan harga input (pupuk } \\
\text { Skenario III }\end{array}$ & $\begin{array}{l}121.452 .650 \\
\text { organik, bibit) 10\% }\end{array}$ & 11,89 \\
\hline
\end{tabular}

Hasil analisis menunjukkan bahwa pada kondisi tersebut terjadi pengurangan nilai keuntungan sebesar 11,89 persen dari keadaan optimal awal sebelum perubahan. Selisih keuntungan pada perubahan harga output dan input ini ternyata memiliki nilai selisih yang lebih besar dibandingkan dengan selisih skenario satu dan dua sebelumnya masingmasing penurunan harga output dan kenaikan harga input 10 persen. Adapun pengaruhnya terhadap produksi optimalnya adalah pada jenis sayur optimal tetap sama namun ada beberapa perbedaan pada jumlah produksinya, namun untuk sumberdaya optimalnya juga kurang lebih sama, hanya nilai surplus dan dual dari masing-masing sumberdaya ada perbedaan. Tabel 8 menunjukkan perubahan keuntungan dari tiga skenario akibat perubahan harga output dan input produksi perusahaan.

Dari hasil analisis post optimalitas di atas merupakan alternatif kebijakan yang dapat diambil oleh perusahaan sesuai kondisi yang dihadapi perusahaan. Hasil analisis menunjukkan bahwa kondisi perubahan peningkatan harga input berupa pupuk organik dan bibit sebesar
10 persen akan menurunkan nilai keuntungan yang diperoleh dari kondisi optimal semula, namun pengaruhnya tidak begitu besar terhadap pengurangan keuntungan yaitu sebesar 1,13 persen. Sementara itu kondisi optimal yang dihadapi perusahaan apabila terjadi penurunan harga output dan juga pada keadaan yang sama juga terjadi kenaikan harga input maka akan mengurangi keuntungan perusahaan dan pengurangan keuntungan pada kondisi post optimalnya cukup besar yaitu keuntungan akan berkurang sebesar 11,89 persen. Gambaran tersebut memberikan informasi terhadap perusahaan bahwa perusahaan harus mengantisipasi produksi pada saat terjadi perubahan yang bersamaan antara penurunan harga output dan peningkatan harga input dikarenakan penurunan keuntungan yang begitu besar saat kondisi optimalnya.

\section{Simpulan}

\section{SIMPULAN DAN SARAN}

1. Yayasan Bina Sarana Bakti sebagai perusahaan agribisnis bergerak dalam bidang sayuran organik belum berproduksi secara optimal, kom- 
binasi pola tanam 35 crop sayur organik pada kondisi aktual mengalami perubahan pola tanam menjadi 28 crop pada kondisi optimal dengan empat macam usia tanaman sesuai dimensi waktu masing-masing disamping itu terjadi peningkatan pada kuantitas sayuran organik yaitu jumlah produksi sayur organik kondisi aktual sebesar 7.110,1 kg mengalami peningkatan menjadi 10.219,11 kg pada kondisi optimal, sedangkan sumberdaya lahan yang digunakan sebesar 10064,38 m2 pada kondisi optimal dengan surplus sumberdaya lahan sebesar 1.125,62 m2 artinya bahwa sumberdaya yang ada belum digunakan secara optimal ditandai dengan adanya sumberdaya lahan berlebih namun sumberdaya lainnya berupa modal dan tenaga kerja sudah digunakan secara optimal.

2. Kondisi optimal perusahan berdampak pada terjadinya perubahan keuntungan dari keadaan aktual dimana dalam kondisi optimal keuntungan perusahaan masih dapat ditingkatkan sebesar 57,86 persen dari keuntungan kondisi aktual.

3. Perubahan yang terjadi dengan adanya penurunan harga output dan kenaikan harga input masing-masing sebesar 10 persen akan mengurangi keuntungan perusahaan sebesar 11,89 persen. Kondisi tersebut merupakan kondisi dengan penurunan keuntungan terbesar yang perlu diantisipasi oleh perusahaan. Perubahan peningkatan harga input berupa pupuk organik dan bibit sebesar 10 persen akan menurunkan nilai keuntungan yang diperoleh dari kondisi optimal semula sebesar 1,13 persen. Sementara itu penurunan harga output sebesar 10 persen akan mengurangi keuntungan sebesar 10,83 persen.

\section{Saran}

Saran yang dapat dikemukakan berkaitan dengan hasil penelitian ini adalah:

1. Keadaan aktual yang masih jauh dari kondisi optimal produksi sayuran organik perusahaan membuat instansi terkait perlu memperhatikan keadaan sumberdaya yang belum digunakan secara optimal, sumberdaya yang perlu dikurangi adalah lahan dan sumberdaya yang perlu ditingkatkan terutama adalah jumlah tenaga kerja dan selanjutnya modal.

2. Yayasan Bina Sarana Bakti perlu mengantisipasi produksi pada saat terjadi perubahan yang bersamaan antara penurunan harga output dan peningkatan harga input dikarenakan penurunan keuntungan yang cukup besar saat perusahaan mengalami keadaan tersebut.

3. Saran penelitian lanjutan sebaiknya dilakukan penelitian lanjut terkait optimasi produksi tiap-tiap musim tanam yang dilakukan untuk melihat perbedaan kondisi optimal setiap musim tanam dengan kondisi iklim yang berbeda-beda tiap musim tanamnya.

4. Analisis optimasi terhadap komoditas pertanian organik (selain komoditas sayuran organik) juga perlu dilakukan untuk melihat peluang bisnis organik dari tingkat pendapatan yang 
diperoleh pada perusahaan organik lainnya.

\section{DAFTAR PUSTAKA}

Ariesusanty L, S Nuryanti, R Wangsa. 2010. Statistik Pertanian Organik Indonesia. AOI, Bogor.

Astuti M. 2007. Optimalisasi Produksi Sayuran Hidroponik PT Saung Mirwan di Desa Sukamanah Kecamatan Mega Mendung [Skripsi]. Institut Pertanian Bogor, Bogor.

Chaerunnisa. 2007. Optimalisasi Pola Tanam Sayuran di Kawasan Agropolitan Babelan, Jawa Barat. [skripsi]. Bogor (ID): Fakultas Pertanian. Institut Pertanian Bogor.

Diatin. 2006. Optimalisasi Produksi Udang Beku Pada PT Wirontono Baru. Buletin Ekonomi Perikanan, 6 (3): 1-14.

Khalik R. 2013. Optimasi Pola Tanam Usahatani Sayuran Selada dan Sawi di Daerah Produksi Padi (Studi Kasus Desa Lam Seunong, Kecamatan Kota Baro, Kabupaten Aceh Besar). Agrisep 14 (1) : 1927.

Maudi F. 2011. Model Usahatani Terpadu Sayuran Organik-Hewan Ternak (Studi kasus Gapoktan Pandan Wangi, Desa Karehkel, Kecamatan Leuwliang, Kabupaten Bogor). Jurnal Forum Agribisnis. 1(1) : 7694.

Puspitasari E. 2013. Optimalisasi Usahatani Padi dan Sayuran Pada Musim Gadu di Kota Singkawang.
Jurnal Social Economic of Agriculture. 2 (2) :75-84.

Rubinos R, Theresa A, Bayacag P. 2007. Comparative Economic Study of Organic and Conventional Rice Farming in Magsaysay, Davao Del Sur.10 th National Convention on Statistics (NCS), EDSA Shangri-La Hotel, Manila.

Soekartawi. 1992. Analisis Usahatani. UI Press, Jakarta (ID).

Sugino T. 2010. Kebijakan Pertanian Daerah di Indonesia pada Era Otonomi Daerah. Laporan Penelitian. JIRCAS, 2(10): 359367.

Sulaeman A. 2009. Konsep dan Pemikiran untuk Menyongsong Revolusi Hijau Kedua dalam Pemikiran Guru Besar IPB Peran Ipteks dalam Pengelolaan Pangan, Energi, SDM dan Lingkungan yang Berkelanjutan. Buku II. IPB Press, Bogor.

Suratiyah K. 2006. Ilmu Usahatani. Penebar Swadaya. Jakarta

Taufik M. 2012. Strategi Pengembangan Agribisnis Sayuran di Sulawesi Selatan. Jurnal Litbang Pertanian. 31 (2): 43-50.

Wicaksono D. 2006. Analisis Pendapatan Usahatani dan Optimalisasi Pola Tanam Sayuran (Desa Cipendawa, Kecamatan Pacet, Kabupaten Cianjur). Departemen Ilmu Sosial Ekonomi Pertanian, Fakultas Pertanian Unstitut Pertanian Bogor. Bogor.

Widiarta A. 2011. Analisis Keberlanjutan Praktik Pertanian Organik Di Kalangan Petani Kasus:Desa Ketapang Kecamatan 
Susukan.(ID): Institut Pertanian Bogor, Bogor. 